\author{
Гмиря В.П. \\ кандидат економічних наук, доцент \\ кафедра економіки, підприємництва та маркетингу \\ Черкаський державний бізнес коледж \\ вул. В.Чорновола, 243/1, м.Черкаси, Україна, 18028 \\ E-mail: viktoryagmirya@ukr.net \\ ORCID ID: 0000-0003-3070-0158
}

\title{
ПРОБЛЕМИ ФУНКЦІОНУВАННЯ РИНКУ ХАРЧОВИХ ПРОДУКТІВ У КОНТЕКСТІ ЗАБЕЗПЕЧЕННЯ ПРОДОВОЛЬЧОЇ БЕЗПЕКИ УКРАЇНИ
}

Проблема продовольчої безпеки є актуальною в усі часи, оскільки рівень харчування населення характеризує рівень економічного розвитку країни, а рівень забезпечення населення продовольчими товарами розглядається як найважливіший фактор і $є$ визначальним критерієм оцінки соціального життя, життєздатності економічної структури і державного устрою країни в цілому. В науковому дослідженні розглянуто стан забезпечення продовольчими товарами населення України. Визначено основні проблеми, які впливають на виробництво та забезпечення продуктами харчування населення країни, серед яких ключовими є: економічна доступність продуктів харчування, рівень розподілу доходів населення, безпека харчових продуктів для здоров'я населення, забезпечення продовольчої безпеки країни та створення необхідних страхових резервів, створення запасів страхових резервів продовольчих товарів. Запропоновано основні напрями виходу з кризи продовольчої безпеки країни, шляхом визначення переліку основних продуктів харчування; розробити порогові значення показників продовольчої незалежності по найважливіших видах продовольства; визначити мінімальний рівень стратегічних резервів і запасів продовольчих ресурсів.

Ключові слова. Продовольча безпека, харчові технології, економічна безпека, продовольче забезпечення, доходи.

This work is licensed under a Creative Commons Attribution 4.0 International License http://creativecommons.org/licenses/by/4.0/

Постановка проблеми та їі зв'язок 3 важливими науковими та практичними завданнями. Незалежно від рівня соціально-економічного розвитку, будь-яка країна прагне вирішити проблему повного забезпечення населення продовольчими товарами. У розвинених країнах виробництво аграрної продукції, іiі переробка та зберігання - це найважливіша умова продовольчої стабільності. Залежність від імпорту найважливіших продуктів харчування робить країну вразливою в разі різкого зростання цін. Рівень забезпеченості якісними продуктами харчування впливає не тільки на соціально-економічну ситуацію в країні, але і на добробут громадян. Продовольча безпека являє такий стан економіки, в рамках якого забезпечується незалежність в сфері продовольства, а фізична і економічна доступність сільськогосподарської продукції гарантується населенню в обсягах, відповідних медичними нормами споживання. Ефективність діяльності в основних галузях сільського господарства, харчової промисловості та інфраструктури, стабільне зростання української економіки і окремих регіонів відносяться до найважливіших умов досягнення продовольчої безпеки.

Аналіз останніх досліджень і публікацій. Дослідженню проблеми продовольчої безпеки та розвитку ринку харчових технологій присвячено грону праць таких зарубіжних та вітчизняних науковців, як: О. А. Богданович, Р. П. Мудрак, В. В. Немченко, Б. Й. Пасхавер, П. Г Саблук, І. В. Федулова, О. М. Шпичак, О. В. Шубравська, В. Юрчишин, Д. Антле, А. Сіна, М. Трейсі, П. Самуельсона, Ф. Хайєка, Е. Енгеля та iн.

Вельми дискусійними продовжують залишатися і вимагають дослідження чинники досягнення продовольчої безпеки в умовах невизначеності зовнішнього і внутрішнього середовища, недостатньої обгрунтованості системи субсидування, неефективного механізму взаємовідносин між аграріями на мікрота мезорівнях, і ін. Це вимагає уточнення пріоритетних напрямків забезпечення незалежності в сфері продовольчої безпеки та розвитку ринку харчової промисловості, що визначило мету і завдання роботи.

Формулювання цілей дослідження. Метою даного дослідження є визначення проблем формування продовольчої безпеки та ринку харчових технологій в умовах глобалізації.

Виклад основних результатів та їх обгрунтування. Сучасні умови розвитку аграрного сектору та вітчизняної харчової промисловості викликають необхідність в розробці нових теоретичних підходів і принципів організації виробництв, що мають дозво 
лити успішно вирішувати завдання щодо забезпечення продовольчої безпеки.

Харчова промисловість, яка охоплює галузі, що виробляють товари для кінцевого споживання населенням $\epsilon$ центральною ланкою в забезпеченні продовольчої безпеки.

Харчова промисловість - сектор із значним мультиплікативним ефектом, пов'язаним 3 забезпеченням зростаючого попиту населення на якісну продукцію, з величезним впливом на сільське господарство, транспорт, оптову та роздрібну торгівлю. У харчовій промисловості виділяють групи спеціалізації: м'ясо-молочне рибна, харчосмакова, борошномельнокруп'яна.

Спеціалізація проявляється в споживчих властивості продукту, що виробляється, вимогах до сировини, виробничій базі і ін. Деякі харчові товари виступають і як засоби виробництва, i як предмет споживання.

Оцінка стану продовольчої безпеки країни, 3 одного боку, визначається стабільністю доступу населення до продуктів харчування.

3 іншого боку, рівень продовольчої безпеки характеризується створенням необхідних страхових резервів продовольчих ресурсів і резерву валютних ресурсів, необхідних для імпорту відсутніх продовольчих товарів, для забезпечення продовольчої незалежності країни, яка є важливим елементом національної безпеки. У цьому контексті продовольча безпека країни забезпечується не тільки сукупністю економічних і соціальних умов, пов'язаних 3 розвитком сільського господарства і виробництвом продуктів харчування, а й загальним станом національної і світової економіки.

У зв'язку 3 тим, що можливість купувати продукти харчування залежить в основному від рівня доходів населення, раціон харчування різних соціальних категорій помітно варіюється.

Помітна різниця в рівні споживання продовольства спостерігається залежно від місця проживання населення: в міській чи сільській місцевості. Раціон сільських жителів, перевершуючи раціон міських жителів за енергетичною цінністю, як правило, поступається за обсягом споживаних цінних продуктів тваринного походження, а також фруктів і ягід.

Сьогодні українська харчова промисловість, яка є складовою АПК, об'єднує понад 40 підгалузей $\mathrm{i}$ виробництв, у яких задіяні близько 15 тисяч суб'єктів господарювання - це і потужні, сучасні підприємства, які стоять на одному рівні з провідними гравцями на світовому ринку, і малі та середні переробники, які активно нарощують обсяги продукції для наповнення внутрішнього ринку та поступово виходять на зовнішні. Найбільша кількість здійснює виробництво м'яса та м'ясопродуктів, олії та тваринних жирів, борошномельно-круп'яної продукції, хліба, хлібобулочних і борошняних виробів (тортів, тістечок), готової їжі та страв.

Задоволення потреб населення у харчових продуктах, у межах його купівельної спроможності, як і у минулі роки, здійснюється, в основному, за ра- хунок продукції вітчизняного виробництва. Фонд забезпечення за основними групами харчування становить близько $90 \%$.

В загальному обсязі промислової продукції харчова переробна промисловість складає 21 відсоток, іiі частка у загальному обсязі ВВП складає 5 відсотків.

За оперативними даними Державної служби статистики, індекс промислової продукції виробництва харчових продуктів, напоїв та тютюнових виробів в Україні (без урахування тимчасово окупованої території АР Крим і м. Севастополя) за 2018 рік, у порівнянні до 2017 року, склав 98,1\% (індекс промислової продукції промисловості в цілому склав 101,1\%, переробної промисловості - 100,2\%).

У грудні 2018 року до грудня 2017 року індекс промислової продукції виробництва харчових продуктів, напоїв та тютюнових виробів склав 94,5\%, до листопада 2018 року $-83,7 \%$ [1].

Збільшилося виробництво у 2018 році порівняно з 2017 роком: яловичини і телятини замороженої (туші, напівтуші) - на 17,3\%, курей, курчат (тушок) заморожених - на 58,9\%, виробів ковбасних на $0,1 \%$, соку томатного - на $7 \%$, соку яблучного - на $41,5 \%$, пюре та паст томатних концентрованих - на $0,2 \%$, овочів (крім картоплі), фруктів, горіхів, грибів та частин рослин їстівних інших, приготовлених чи консервованих 3 додаванням оцту чи оцтової кислоти - на 3,7\%, молока та вершків незгущених й без додавання цукру жирністю $1-6 \%$ - на $6,4 \%$, сиру свіжого неферментованого - на 6,1\%, сиру тертого, порошкового, голубого та іншого неплавленого - на 3,1\%, молока і вершків, коагульованого йогурту, кефіру, сметани - на $1,9 \%$, йогурту рідкого та сквашеного молока ароматизованого - на 8,7\%, гумок, фруктових желе та паст (крім жувальної гумки) - на 3,3\%, спредів та сумішей жирових - на 37,9\%, лікерів та інших спиртних напоїв - на $16,4 \%$, пива солодового - на $1,4 \%$, вод натуральних мінеральних негазованих - на $20,4 \%$, вод натуральних мінеральних газованих - на $15,6 \%$, вод 3 додаванням цукру і речовин підсолоджувальних чи ароматизуючих - на 9,3\% [2].

Знизилося виробництво: яловичини і телятини свіжої чи охолодженої (туші, напівтуші) - на 2,2\%, свинини свіжої чи охолодженої (туші, напівтуші) - на 9,3\%, свинини замороженої (туші, напівтуші) - на $17,1 \%$, курей, курчат (тушок) свіжих чи охолоджених - на 19,5\%, курей, курчат (частини тушок) свіжих чи охолоджених - на 10,9\%, суміші соків фруктових $\mathrm{i}$ овочевих - на 1,9\%, олії соняшникової нерафінованої - на 7,7\%, маргарину і продуктів пастоподібних - на $3,3 \%$, молока та вершків не згущених й без додавання цукру жирністю не більше 1\% - на 3,1\%, масла вершкового жирністю не більше $85 \%$ - на 1,7\%, борошна пшеничного чи пшенично-житнього - на 13,9\%, хліба та виробів хлібобулочних - на 9,6\%, печива солодкого (що не мстять шоколаду та какао) - на 2,9\%, цукру білого кристалічного бурякового - на 12,6\%, цукерок шоколадних (що не містять алкоголю) - на 0,2\%, виробів кондитерських 3 цукру чи його замінників, 3 вмістом какао - на 8,3\%, карамелі, тофі - на 3,8\%, 
соусів, приправ і прянощів - на 2,2\%, продуктів молоковмісних - на 5,5\%, коньяку, бренді - на 5,7\%, горілки з вмістом спирту менше 45,4\% - на 7,1\%, сигарет, які містять тютюн, або суміші тютюну - на $8,7 \%[1,2]$.

За даними Держстату за 2018 рік реалізовано продукції виробництва харчових продуктів, напоїв та тютюнових виробів на суму 505,4 млрд. грн, що складає $20,2 \%$ в загальному обсязі реалізованої промислової продукції України. За цим показником сектор вийшла на перше місце серед всіх галузей промисловості.

Експорт продукції харчової промисловості досягнув у 2018 році позначки 9,4 млрд. дол. США, що в загальному обсязі продукції АПК складає $50,2 \%[2]$.

Ключові позиції в експорті продуктів переробки займають: соняшникова олія $-4,1$ млрд. дол. США, макуха та інші тверді відходи від видобування рослинних жирів та олій, крім відходів соєвої та арахісової олії - 922 тис. дол. США, м'ясо та субпродукти домашньої птиці - 507 тис. дол. США, тютюнова продукція - 341 тис. дол. США, цукор - 217 тис. дол. США, вироби з шоколаду - 171 тис. дол. США, макуха та інші тверді відходи соєвої олії - 162 тис. дол. США, кондитерські вироби з цукру - 135 тис. дол. США, хлібобулочні, кондитерські вироби - 153 тис. дол. США, олія соєва - 153 тис. дол. США, масло вершкове та інші жири вироблені з молока - 129 тис. дол. США, олія зі свиріпи, ріпакова або гірчична 112 тис. дол. США [1].

Основними проблемами організації ринку харчових продуктів, а отже і продовольчої безпеки країни в цілому можна виділити наступні.

1. Економічна доступність. Економічна доступність має на увазі, що всі верстви населення мають достатньо коштів для придбання продовольчих товарів та забезпечення повноцінного харчування. Оцінку економічної доступності продуктів харчування в цілому по країні можна проводити на основі аналізу наступних показників:

- обсяг валового внутрішнього продукту (ВВП) на душу населення;

- частка витрат на продукти харчування в споживчих витратах домашніх господарств;

- масштаби поширення бідності в країні (частка населення з рівнем доходів (витрат) нижче прожиткового мінімуму / межею бідності, частка населення, що має доходи нижче меж бідності, встановлених на міжнародному рівні, і частка вартості мінімального набору продуктів харчування в загальній величині прожиткового мінімуму);

- нерівномірність розподілу грошових доходів серед населення; населення;

- купівельна спроможність грошових доходів

- рівень споживчих цін на продукти харчування.

Доступність продовольства в економічному сенсі, в основному, визначається рівнем життя насе- лення, оскільки він характеризує потреба, зокрема, в продуктах харчування і можливість їх задоволення виходячи 3 пропозицій на ринку товарів і послуг, а також реальних доходів людей.

У світовій практиці для зіставлення рівня життя в різних країнах використовують обсяг ВВП в доларах США на душу населення, обчислити який можна двома способами:

1) за обмінним курсом;

2) на основі паритету купівельної спроможності валют (ПКС).

Частка витрат на продукти харчування в споживчих витратах домашніх господарств також $є$ одним 3 важливих соціально-економічних індикаторів, що характеризують рівень життя, а, отже, і економічну доступність продуктів харчування. В більшості країн Європейського союзу питома вага витрат на харчування становить 20-25\% споживчих витрат домашніх господарств. Населення України змушене витрачати на їжу набагато більшу частину своїх коштів (40-50\% і вище від споживчих витрат).

Нерівномірність розподілу доходів у суспільстві також може негативно впливати на рівень економічної доступності продовольчих ресурсів. Причини нерівності доходів можуть залежати від інтелектуальних і фізичних здібностей, освіти, наявності власності (для отримання додаткових доходів), дискримінації в прийомі на роботу або невиправдано низьку оплату праці.

Для кількісної оцінки нерівномірності розподілу доходів використовують коефіцієнт фондів, що характеризує масштаб соціального розшарування, i коефіцієнт Джині, який показує диференціацію грошових доходів населення у вигляді ступеня відхилення фактичного розподілу доходів від абсолютно рівного їх розподілу між жителями країни.

Коефіцієнт фондів розраховується як:

$$
K_{f 10}=\frac{S_{10}}{S_{1}}
$$

де:

$\mathrm{S}_{10}$ i $\mathrm{S}_{1}$ - сумарні значення грошових доходів в 10-ій і 1-ій децильних групах.

Коефіцієнт Джині (індекс концентрації доходів) - показник, характеризує ступінь відхилення фактичного розподілу загального обсягу доходів населення від лінії їх рівномірного розподілу. Коефіцієнт Джині змінюється від 0 до 1; чим ближче значення показника до 1, тим більш нерівномірно розподілені доходи в суспільстві. коефіцієнт Джині можна розрахувати за формулою:

$$
G=1-2 \sum_{i=1}^{n} x_{i} * \text { cumy }_{i}+\sum_{i=1}^{n} x_{i} y_{i}
$$

де:

$G$ - коефіцієнт Джині;

cum $y_{i}$ - кумулятивна частка обсягу доходів;

$x_{i}$ - частка населення в кожному інтервалі;

$y_{i}$ - частка обсягу доходів, що припадають на кожен інтервал. 
За допомогою коефіцієнтів нерівномірності можна проводити порівняльний аналіз становища 3 розподілом доходів в країні і тим самим визначати ефективність політики державних структур по пом'якшення нерівності в суспільстві.

Забезпечення економічної доступності продовольства передбачається досягати шляхом впливу на рівноважний рівень цін продуктів харчування і на доходи населення. При цьому в країні повинні бути створені умови, що гарантують можливість для всіх соціальних груп населення споживати продукти харчування відповідно до медичних норм та якості.

2. Безпека харчових продуктів для здоров'я. В останні роки все більш актуальною стає проблема забезпечення населення якісними продуктами харчування. Харчові ланцюги є одним з основних шляхів надходження шкідливих речовин в організм людини. Неякісне харчування, по суті, є міною уповільненої дії. В результаті тривалого прийому неякісної їжі імунітет в організмі людини послаблюється, всі процеси відбуваються дуже повільно, посилюються хронічні захворювання, що зрештою перетворюється на чинник ризику, що провокує безліч захворювань.

Об'єктивність визначення якості продукції особливо ускладняється останніми роками у зв'язку із подрібненням товаровиробників i збільшенням їх кількості, послабленням навичок, потрібних для контролю за якістю реалізованої продукції. На сьогодні в особистих селянських господарствах виробляється близько 80\% молока, 95 - картоплі, 80 - овочів, 50\% м'яса і фруктів тощо. Якісні показники реалізованої товаровиробниками продукції визначають лабораторії заготівельника здебільшого практично «наосліп» для здавальника продукції, тому точність їх визначення повністю залежить від сумлінності працівників сировинних лабораторій заготівельних організацій.

3 об'єктивних причин проблему неналежної якості аграрної продукції можна розв'язувати лише в разі досягнення певного обсягу виробництва продуктів харчування, ліквідації ії дефіцитності та досягнення високого рівня купівельної спроможності людей.

3. Забезпечення продовольчої безпеки країни та створення необхідних страхових резервів. Продовольча незалежність будь-якої країни багато в чому визначаються рівнем, ефективністю і стійкістю розвитку сільського господарства. У тих країнах, де проводиться недостатньо продовольчих товарів 3 власної сировини, виникає кон'юнктурна залежність від інших держав. До важливих критеріїв продовольчої безпеки відноситься наявність стратегічних запасів продовольчих товарів, достатнього для забезпечення населення в кризовій ситуації; необхідний також резерв валютних ресурсів, для імпорту відсутніх товарів.

Для досягнення продовольчої безпеки аграрна політика держави повинна бути спрямована на фінансову та цінову підтримку сільськогосподарських виробників 3 використанням системи компенсацій і дотацій, пільгового оподаткування та кредитування, забезпечення інвестиційного процесу, цінових і закупівельних заходів. Ці заходи щодо сільськогосподарського виробництва пов'язані з особливою вразливістю цієї галузі господарства, високим ступенем залежності від кліматичних і природних чинників, 3 історичними традиціями населення, міграційними процесами та іншими факторами невизначеності, що надають безпосередній вплив на результати сільськогосподарської діяльності людей.

4. Запаси страхових резервів продовольчих товарів. Важливим критерієм продовольчої безпеки є наявність страхових (стратегічних) запасів продовольства, достатнього для забезпечення населення в кризовій ситуації на період мобілізаційних заходів по перебудові системи життєзабезпечення країни з метою подолання або компенсації збитку, нанесеного кризовою ситуацією. Найважливішим продуктом, в плані стратегічних запасів, є зерно, оскільки воно споживається в основному на харчові цілі, зберігає якісні і кількісні параметри при транспортуванні, придатне до тривалому зберіганню і створює можливість формування страхових і резервних фондів. Всі ці якості надають зерну пріоритетне значення в досягненні продовольчого самозабезпечення держави.

Основні проблеми, які обмежують розвиток виробництва харчової продукції, а отже і харчових технологій - це:

- нестабільність забезпечення підприємств харчової промисловості сировиною. На сьогодні сільськогосподарські виробники, переробні і торгові підприємства не завжди виконують свої обов'язки один перед одним, а отже порушуються терміни поставки сировини, що в свою чергу не дозволяє своєчасно виконувати поставлені завдання перед галузями.

- низька конкурентоспроможність українських харчових продуктів порівняно 3 аналогічною продукцією країн ЄС і розвинених країн світу. Основним чинником, який вливає на дану проблему $є$ не до укомплектованість харчової промисловості новітніми технологіями, або застарілими.

- низький рівень відтворення основних засобів та відсутність кваліфікованих кадрів, які б забезпечували розвиток галузі.

- ускладнення доступу до фінансування. Не лише харчова промисловість має проблеми 3 доступом до ринку кредитних ресурсів, а сільськогосподарські товаровиробники та переробні підприємства, в силу відсутності програм підтримки цих галузей.

- відсутність єдиних технічних і санітарних стандартів системи сертифікації харчових продуктів. Це призводить до того, що якість продукції не відповідає нормам.

Висновки та перспективи подальших досліджень. Забезпечення продовольчої безпеки є ключовою глобальною проблемою і одним 3 основних завдань України на шляху економічної незалежності. В науковому дослідженні проведено аналіз ситуації 3 продовольчою безпекою в Україні та надано оцінку основних причин продовольчих проблем, до яких відносяться: демографічна ситуація, виснаження природних ресурсів для виробництва продуктів харчування, трансформація структури споживання, втрати 
харчових продуктів і харчові відходи, виробництво біопалива, зростання світових цін на продукти харчування, кризи і конфлікти.

В якості пріоритетних напрямів забезпечення продовольчої безпеки на макро - і мезорівнях слід запропонувати та визначити подальші дослідження щодо питань:

- організації і проведення моніторингу регіонального аграрного ринку з використанням департаментів регіонального розвитку на місцевому рівні, департаментами Міністерства розвитку економіки, торгівлі та сільського господарства. - на національному і міждержавному рівнях (зростання доступності аграрної продукції шляхом повернення регулювання цін; розвиток міжрегіональної інтеграції у сфері аграрних ринків і продовольчого забезпечення; вдосконалення системи організації контролю безпеки харчових продуктів, включаючи створення сучасної техніко-технологічної і методичної бази; зниження рівня бідності, забезпечення пріоритетної підтримки найбільш нужденних верств населення; зростання обсягів сільськогосподарського виробництва, за рахунок зростання родючості грунтів, урожайності і продуктивності сільськогосподарської продукції; створення нових технологій переробки продовольчої сировини, методів зберігання і транспортування);

- формування механізмів і регуляторів державної підтримки вітчизняних сільськогосподарських товаровиробників у сфері інвестиційної та інноваційної діяльності (соціально-економічне облаштування сільських територій, зростання фінансування та реалізація соціальних програм в регіонах, моніторинг рівня безробіття і реальних доходів сільського населення, диверсифікація зайнятості сільського населення, контроль ефективності роботи систем санітарного, ветеринарного та фітосанітарного контролю, підвищення конкурентоспроможності товарів вітчизняного виробництва за рахунок поліпшення якості продукції).

Забезпечення продовольчої безпеки має грунтуватися на підвищенні інвестиційної активності товаровиробників та створення сприятливих умов з боку держави для конкурентоспроможного розвитку сільського господарства.

\section{Література}

1. Розвиток харчової переробної промисловості за 2018 рік: веб-сайт. URL: https://agro.me.gov.ua/ua/napryamki/prodovolstvo/pidsumki-diyalnosti-pidpriyemstv-harchovoyi-ta-pererobnoyipromislovosti/rozvitok-harchovoyi-pererobnoyi-promislovosti-za-2018-rik (дата звернення 10.01.2020)

2. Державний комітет статистики України: веб-сайт. URL: http://www.ukrstat.gov.ua/(дата звернення 10.01.2020)

3. Щербина С.В. Державна політика забезпечення продовольчої безпеки України // Visnyk NAPA. 2014. №2. C.49-35

4. Україна втрачає в вродовольчій безпеці: веб-сайт. URL: http://agroportal.ua/ua/news/ukraina/issledovanie-ukraina-teryaet-v-prodovolstvennoi-bezopasnosti/ (дата звернення 15.01.2020)

5. Яковенко О.В. Розробка механізму зміцнення продовольчої безпеки України шляхом фінансової підтримки сільськогосподарських підприємств: зб. наук. праць Черкаського державного технологічного університету. 2017. Том 2, № 45. С.103-109

6. Кириленко І.Г., Івченко В.С., Дем'янчук В.В. Продовольча безпека України в світлі сучасних тенденцій світової економіки // Економіка АПК. 2017. № 8. С. 5-14

7. The Eurasian Wheat Belt and Food Security : Global and Regional Aspects / S. Gomez y Paloma et al. (eds.). Springer International Publishing Switzerland, 2017. 318 p.

8. Волченко Н. В. Продовольча безпека: теоретичні аспекти та реалії сьогодення // Система національного менеджменту в контексті інтеграційного виміру: монографія / за наук. ред. д.е.н., проф. Л.І. Михайлової. Суми: ПП Вінниченко М. Д., ФОП Литовченко С. Б., 2014. С. 38 - 57

9. Гайдуцький П.І. Україні потрібна нова аграрна політика // Економіка АПК. 2005. №10. С. 3-7.

10. Achieving Zero Hunger: The Critical Role of Investments in Social Protection and Agriculture. URL: http://www.fao.org/3/a-i4951e.pdf. (retrieved 15.01.2020) 
Гмыря В.П.

кандидат экономических наук, доцент

кафредра экономики, предпринимательства и маркетинга

Черкасский государственный бизнес колледж

ул. В. Черновола, 243/1, г. Черкассы, Украина, 18028

E-mail: viktoryagmirya@ukr.net

ORCID ID: 0000-0003-3070-0158

\section{ПРОБЛЕМЫ ФУНКЦИОНИРОВАНИЯ РЫНКА ПРОДОВОЛЬСТВИЯ В КОНТЕКСТЕ ОБЕСПЕЧЕНИЯ ПРОДОВОЛЬСТВЕННОЙ БЕЗОПАСНОСТИ УКРАИНЫ}

Проблема продовольственной безопасности является актуальной в каждой стране, поскольку уровень питания характеризует уровень экономического развития страны, а уровень обеспечения населения продовольственными товарами рассматривается как фундаментальный фрактор оценки жизнеспособности экономической структуры и государственного устройства страны в целом.

В научном исследовании рассмотрено состояние обеспечения продовольственными товарами населения Украины. Выявлено, что индекс промышленной продукции производства пищевых продуктов, напитков и табачных изделий в Украине (без учета временно оккупированной территории АР Крым и г. Севастополя) по 2018 год, составил 98,1\%, что в сравнении с другими видами промышленности значительно ниже. Определены основные проблемы, которые влияют на производство и обеспечение продуктами питания населения страны, среди которых ключевыми являются: экономическая доступность продуктов питания, уровень распределения доходов населения, безопасность пищевых продуктов для здоровья населения, обеспечения продовольственной безопасности страны и создания необходимых страховых резервов, создания страховых запасов резервов продовольственных товаров.

На сегодня Украина занимает 63 место в рейтинге Глобального индекса продовольственной безопасности, что на 5 мест ниже, чем в 2014 году. Поэтому необходимо все больше внимания уделять продовольственной безопасности и развития таких отраслей как сельское хозяйство и пищевая промышленность, поскольку они являются фундаментом в обеспечении продовольственной безопасности.

Предложены основные направления выхода из кризиса продовольственной безопасности страны, путем определения перечня основных продуктов питания, которые наиболее достоверно отражающих структуру рациона питания основных групп населения; на основе установленных или рекомендованных медицинскими учреждениями рациональных норм потребления по отобранному перечню продуктов питания вычислить базовые параметры потребления на душу населения за год, отражающие объем потребности, который не ограничен доходами и ресурсными возможностями страны; разработать пороговые значения показателей продовольственной независимости по важнейшим видам продовольствия; определить минимальный уровень стратегических резервов и запасов продовольственных ресурсов.

Ключевые слова: продовольственная безопасность, пищевые технологии, экономическая безопасность, продовольственное обеспечение, доходы.

Hmyria V.

Ph.D., Associate Professor

Department of Economics, Entrepreneurship and Marketing,

Cherkasy State Business College,

st. V. Chornovola, 243/1, Cherkasy, Ukraine, 18028

E-mail: viktoryagmirya@ukr.net

ORCID ID: 0000-0003-3070-0158

\section{PROBLEMS OF FOOD MARKET FUNCTIONING IN THE CONTEXT OF PROVISION OF UKRAINE'S FOOD SAFETY}

The issue of food security is relevant at all times, as the level of nutrition of the population characterizes the level of economic development of the country, and the level of provision of population with food products is considered as the most important factor and is the determining criterion of social life, the viability of economic structure and government of the country as a whole. 
The scientific study examines the state of providing food products of the population of Ukraine. It is revealed that the industrial production index of food, beverages and tobacco in Ukraine (excluding the temporarily occupied territory of Crimea and Sevastopol) up to 2018 , was $98.1 \%$, which in comparison with other industries is much lower. The key problems affecting the production and provision of food of the population, among which the main are: economic accessibility of food, the level of income distribution, food safety for public health, ensuring food security and creating necessary insurance reserves, the establishment of insurance reserves of food products, have been identified.

Today Ukraine ranks 63rd in the rating of Global index of food security, which is 5 places lower than in 2014. So, all you need is to pay more attention to food security and development of such sectors as agriculture and food industry, as they are fundamental to ensure food security.

The basic directions of overcoming the crisis of food security have been proposed by defining a list of basic foods that most reliably reflect the structure of the diet of key groups of populations; on the basis of established or recommended, by healthcare institutions, rational norms of consumption on the selected list of foods to calculate the basic parameters of consumption per capita per year, reflecting the demand quantity, which is not restricted to income and resource potential of the country; to develop threshold values of indicators of food sovereignty on the most important types of food; to determine the minimum level of strategic reserves and stockpiles of food resources.

Key words: food safety, food technology, economic security, food security, income.

\section{References}

1. Rozvytok kharchovoi pererobnoi promyslovosti za 2018 rik. Retrieved January 10, 2020, from https://agro.me.gov.ua/ua/napryamki/prodovolstvo/pidsumki-diyalnosti-pidpriyemstv-harchovoyi-ta-pererobnoyipromislovosti/rozvitok-harchovoyi-pererobnoyi-promislovosti-za-2018-rik

2. Derzhavnyi komitet statystyky Ukrainy. Retrieved January 10, 2020, from http://www.ukrstat.gov.ua/

3. Shcherbyna, S. V. (2014). Derzhavna polityka zabezpechennia prodovolchoi bezpeky Ukrainy. Visnyk NAPA, (2), 35-49.

4. Ukraina vtrachaie v prodovolchii bezpetsi. (2018). Retrieved January 15, 2020, from http://agroportal.ua/ua/news/ukraina/issledovanie-ukraina-teryaet-v-prodovolstvennoi-bezopasnosti/

5. Yakovenko, O. V. (2017). Rozrobka mekhanizmu zmitsnennia prodovolchoi bezpeky Ukrainy shliakhom finansovoi pidtrymky silskohospodarskykh pidpryiemstv. Zb. Nauk. Prats Cherkaskoho Derzhavnoho Tekhnolohichnoho Universytetu, 2(45), 103-109.

6. Kyrylenko, I. H., Ivchenko, V. Ye., \& Dem'ianchuk, V. V. (2017). Prodovolcha bezpeka Ukrainy v svitli suchasnykh tendentsii svitovoi ekonomiky. Ekonomika APK, (8), 5-14.

7. Gomez y Paloma, S. (Ed.). (2017). The Eurasian Wheat Belt and Food Security : Global and Regional Aspects. Springer International Publishing Switzerland. doi: 10.1007/978-3-319-33239-0

8. Volchenko, N. V. (2014). Prodovolcha bezpeka: teoretychni aspekty ta realii sohodennia. In L. I. Mykhailova (Ed.), Systema natsionalnoho menedzhmentu v konteksti intehratsiinoho vymiru. Sumy: PP Vinnychenko M. D., FOP Lytovchenko Ye. B.

9. Haidutskyi, P. I. (2005). Ukraini potribna nova ahrarna polityka. Ekonomika APK, (10), 3-7.

10. Achieving Zero Hunger: The Critical Role of Investments in Social Protection and Agriculture. (2015). Retrieved January 15, 2020, from http://www.fao.org/3/a-i4951e.pdf

Received 18 January 2019

Approved 1 February 2019

Available in Internet 31.03.20

Цитування згідно ДСТУ 8302:2015

Гмиря В.П. Проблеми функціонування ринку харчових продуктів у контексті забезпечення продовольчої безпеки України // Економіка харчової промисловості. 2020. Т.12, вип. 1. С.13-19. doi: 10.15673/fie.v12i1.1664

Cite as APA style citation

Hmyria, V. (2019). Problems of food market functioning in the context of provision of Ukraine's food safety. Food Industry Economics, 12(1), 13-19. doi: 10.15673/fie.v12i1.1664 